\title{
Effects of Application of Barcodes in Wafer Warehouse Process on Work Efficiency and Job Satisfaction-A Case Study of A Semiconductor Packaging and Testing Company A
}

\author{
Ming-LangWang and Chien-LungChen \\ No.707, Sec. 2, WuFu Rd.,, Chung Hua Univ. Hsinchu, Taiwan
}

\begin{abstract}
Wafer warehouses are the first station in a semiconductor packaging and testing company to store wafers. Howe to effectively manage the warehouses is an important issue. Authors of this article conducted questionnaire survey on the persons at wafer warehouse and further testified, in the constructs of work efficiency and job satisfaction, whether the application of barcode system has the managerial effect of significant enhancement of wafer management for a company's wafer warehouse department.
\end{abstract}

Keywords- work efficiency; job satisfaction; barcode system

\section{INTRODUCTION}

The objects of wafer warehouse management are: 1 . Accuracy of storing positions; 2. Transparency in departmental information; and 3. Reduction of manual article picking. Company A, a semiconductor packaging and testing company, had manually maintained the system storing position information and searched for vacant positions for storing wafers till it introduced the barcode system. Manual maintenance tends to have higher rates of incorrect storing position data and thus results in the decreased accuracy of wafer storing positions in the wafer warehouse, which in turn compromises effective wafer management. When the barcode system has been introduced, by reading the information on labels using PDAs and uploading the information to the system database on Cloud, the information on storing positions in the SAP system is automatically maintained, which increases the accuracies of storing positions, reduces the time needed by manual picking, and improves the transparency of departmental information. The job satisfaction in employees that is improved thanks to the barcode system also elevates the total benefit of the wafer warehouse.

\section{LIERATURE REVIEW}

The use of barcodes was first promoted by the National Supermarket Association in U.S. in view of saving massive human power and materials by applying technology in department stores and supermarkets. When officially put to use in 1973, barcodes were dubbed "Universal Product Code", UPC for short, and applied to the North American region including U.S. and Canada. UPC was so popular in U.S. and Canada that Europe followed to introduce the concept and techniques of barcodes and established the "European Article
Number", EAN. Twelve European industrial countries jointly promoted it and executed in 1977 an MOU on establishing the EAN organization for propagating the concept of barcodes to other areas. As such, the barcode systems became globalized. The EAN Standards were introduced in Taiwan in 1986 and soon supported by the government with policy in place, which caused barcodes to be widely used to commodities in Taiwan. In late 2002, U.S. and Canada, representing UCC, together, joined the EAN organization, which really brought together the two major international organizations that had led commodity coding and promoted electronic commerce as one. And, after the discussion at the council in 2003 and the formulation by a planning panel in 2004, in 2005 a unified GS1 organization for global standards was officially announced. In the EAN/UCC system, identification numbers of commodity are all converted into the form of barcode, whereby to show the identification numbers for ease of automatic acquisition of data by machines to increase the efficiency of reading commodity information. Apart from the processes of manufacture and logistics that share the barcodes, the same barcodes can also be used in identification and tracking. Admittedly, barcodes play an essential and key role in automated management of goods.

The company under study chooses $2 \mathrm{D}$ barcodes to use in its wafer warehouse because it has great quantities of articles in demand and sizes of information. 2D barcodes hold great amount of information, is highly secure and well damageresistant, while the barcode system features good reliability, high efficiency, low cost, easy to make and operate, as well as hard- and software both easy to setup, the system makes a perfect tool for executing improvement at low costs.

\section{RESEARCH METHOD}

This study conducted Descriptive Research with the subjects of employees at wafer warehouse of the production management department in a semiconductor packaging and testing company A. We designed questionnaires with the key factors obtained from expert interviews to explore the barcode system's benefits for the wafer warehouse in the constructs of work efficiency and job satisfaction. The questionnaires were used to conduct factor analysis and validity analysis.

1. Persons whom the questionnaire targeted and was distributed to: in the organization of the wafer warehouse 
personnel at Company A, eight shifts, which are the day shift and the night shift around the clock, each person works two and has two off, are arranged for each of FC, CP and WDPS; each shift comprises 10 production management line workers, charged with assisting in putting the wafers on the production line, breaking batches and sending for QA inspection. For wafer receiving, a total of 70 workers in both day shift and the night shift perform the receiving of incoming materials and maintenance of storing positions.

\section{A. Methodology}

\section{1) Descriptive statistics}

Doing the statistics of the variables in the retrieved samples and using the frequency distribution table to understand the basic information of the respondents can lead to the knowledge of the distribution of their genders, length of employment and education background.

\section{2) Reliability analysis}

Reliability analysis assesses how reliable a scale is; it also is an index for consistence and stability of the scale.

The internal consistence between the barcode system and the constructs of wafer warehouse operations is tested with Cronbach's $\alpha$.

Above a baseline of 0.7 , a greater value of Cronbach's $\alpha$ indicates greater correlation between the items within a construct, i.e., a higher internal consistence.

\section{3) Factor analysis:}

An inter-dependent method of analysis and a multivariable analysis; in fact, it is intended to reduce a great number of variables to only a few meaningful factors, and, in turn, realize the extraction of information.

The factor analysis in this study involves the following steps:

2. KMO measure of sampling adequacy test and Bartlett Sphericity Test, with KMO value above 0.7 considered optimal.

3. Principal component analysis of the factor analysis that followed the KMO analysis is used to extract common factors by the criteria of eigenvalue greater than 1 for the number of factors to be chosen.

4. Select the factors with factor loading greater than 0.45 as constructs and rename them.

(4) One-way ANOVA

Analysis Of Variance (ANOVA), which involves only one dependent variable (metric) and one or more independent variables (non-metric, nominal), is expressed as follows:

$$
\text { (metric) } \quad \begin{aligned}
& \mathrm{Y} 1=\mathrm{X} 1+\mathrm{X} 2+ \\
& \text { (non-metric) }
\end{aligned}
$$

An ANOVA that involves only one independent variable is called one-way ANOVA.

This study will use the results of one-way ANOVA on the improvement on the work of the workers at each station to testify, by f-test, work efficiencies at Company A after the introduction of barcodes, in terms of reduction of article picking time, accuracy of storing positions, and transparency of information in the production management department; and to find out about the sense of achievement in the employees' job satisfaction and their job satisfaction after the system improvement.

Hypothesis tests in terms of work efficiency and job satisfaction are as follows:

Work efficiency:

H1: The operation after improvement with barcode system and the reduction of article picking time are significant.

$\mathrm{H} 2$ : The improvement with barcode system is significantly related to the accuracy of storing positions at the wafer warehouse.

H3: The improvement with barcode system is significantly related to the information transparency at the production management department.

Job satisfaction

H4: The introduction of barcode system is significantly related to employee's sense of achievement in work.

H5: The introduction of barcode system is significantly related to employee's job satisfaction.

These five hypotheses were testified by analyzing with the criteria of $<\alpha=0.05$ as significance.

\section{RESUlTS}

\section{A. Reliability and Validity of Questionnaires}

During the period of 2015/09/18-2015/10/08, 300 copies of questionnaire were distributed, with 286 copies retrieved as valid questionnaire, representing a retrieval rate at $95.33 \%$. Respondents included 73 workers in the FC line, 77 in the CP line, 71 in the WDPS line, and 67 rewinding persons. Work efficiency had a reliability of Cronbach's Alpha at 0.806, with KMO measure at 0.807 ; job satisfaction had a reliability of Cronbach's Alpha at 0.78 , with KMO measure at 0.777 . The analytic results proved good.

\section{B. Questionnaire Respondents}

Of the respondents, $52.1 \%$ were male and $47.9 \%$ female, the former outnumbering the latter. In terms of work station, 73 persons were flip-chip packaging FC, accounting for $25.3 \%$, 71 were wafer packaging WDPS, $24.7 \%, 77$ were wafer testing $\mathrm{CP}, 26.7 \%$, and 67 were wafer rewinding workers, $23.3 \%$. Education-wise, senior high graduates accounted for $27.8 \%$, undergraduates $67 \%$, and graduate students $5.2 \%$. Regarding length of employment, those having worked under a year accounted for $32.3 \%$, those longer than 1 year but under 5 years, being the majority, $56.9 \%$, and those over 5 years $10.8 \%$. the above information reveals that most the of respondents were undergraduates and have worked for one to five years, who, among the subject herein, were evenly distributed in the three production lines and the receiving persons at the wafer warehouse, such that a non-biased view 
from all relevant fields of persons on the barcode system could be achieved.

The results of KMO sampling adequacy test and Bartlett Sphericity Test showed that for work efficiency, $\mathrm{KMO}=0.807$, and for job satisfaction, $\mathrm{KMO}=0.777$, and the Bartlett Sphericity Test value: 998.48 for work efficiency and 730.224 for job satisfaction, where the significance was all 0.000 , indicating that the data were suitable for factor analysis.

After the test, the principal components analysis in the factor analysis was used to extract the common factors. By the criteria of selecting those with eigenvalue greater than 1 as common factors, four factors were named for each work efficiency and job satisfaction. Their variance explained are as follows:

TABLE I. EIGENVALUE AND VARIANCE EXPLAINED FOR WORK EFFICIENCY

\begin{tabular}{|c|l|c|c|}
\hline \multirow{2}{*}{$\begin{array}{c}\text { Table } \\
\text { Head }\end{array}$} & \multicolumn{1}{|c|}{ Title } & Eigenvalue & $\begin{array}{c}\text { Variance } \\
\text { explained }\end{array}$ \\
\cline { 2 - 4 } Factor 1 & $\begin{array}{l}\text { The barcode system and } \\
\text { storing positions } \\
\text { maintenance }\end{array}$ & 4.107 & $31.591 \%$ \\
\hline Factor 2 & $\begin{array}{l}\text { Functions of the barcode } \\
\text { system }\end{array}$ & 1.587 & $43.798 \%$ \\
\hline Factor 3 & $\begin{array}{l}\text { Management of the barcode } \\
\text { system }\end{array}$ & 1.128 & $52.437 \%$ \\
\hline Factor 4 & $\begin{array}{l}\text { The barcode system and QA } \\
\text { department }\end{array}$ & 1.106 & $60.634 \%$ \\
\hline
\end{tabular}

TABLE II. EIGENVALUE AND VARIANCE EXPLAINED FOR JOB SATISFACTION

\begin{tabular}{|c|l|c|c|}
\hline \multirow{2}{*}{$\begin{array}{c}\text { Table } \\
\text { Head }\end{array}$} & \multicolumn{1}{|c|}{ Title } & Eigenvalue & $\begin{array}{c}\text { Variance } \\
\text { explained }\end{array}$ \\
\cline { 2 - 4 } Factor 1 & $\begin{array}{l}\text { Autonomy and independence of } \\
\text { work }\end{array}$ & 3.521 & $35.208 \%$ \\
\hline Factor 2 & $\begin{array}{l}\text { Factors of barcode system } \\
\text { improvement }\end{array}$ & 1.273 & $47.936 \%$ \\
\hline Factor 3 & $\begin{array}{l}\text { Job satisfaction after } \\
\text { improvement }\end{array}$ & 1.091 & $58.846 \%$ \\
\hline Factor 4 & Job identity & 1.003 & $68.874 \%$ \\
\hline
\end{tabular}

C. Results of One-way ANOVA

1) Work efficiency

a) $H_{1}$ : The operation after improvement with barcode system and the reduction of article picking time are significant.

TABLE III. ONE-WAY ANOVA RESULT OF $\mathrm{H}_{1}$

\begin{tabular}{|l|l|c|c|}
\hline \multirow{2}{*}{ Table Head } & \multicolumn{1}{|c|}{ Title } & F & Significance \\
\cline { 2 - 4 } & \multicolumn{1}{|c|}{} & 0.03 \\
\hline $\begin{array}{l}\text { Independent } \\
\text { variable 1 }\end{array}$ & $\begin{array}{l}\text { The belief that manual recording } \\
\text { is more reliable than the barcode } \\
\text { system }\end{array}$ & 4.27 & 0.02 \\
\hline $\begin{array}{l}\text { Independent } \\
\text { variable 2 }\end{array}$ & $\begin{array}{l}\text { Picking time is reduced due to } \\
\text { the barcode system }\end{array}$ & 7.67 & \\
\hline
\end{tabular}

The analysis of the results showed that both that the production management persons at Company A considered manual recording more reliable than barcode system and picking time reduced due to the barcode system were significant. While with the system introduced, the workers need only to pick the articles at the positions the barcode labels indicate, the automatic maintenance by the system also turn out more reliable than manual recording. Therefore, H1: Operation after improvement with barcode system and the reduction of article picking time are significant.

b) $\mathrm{H}_{2}$ : The improvement with barcode system is significantly related to the accuracy of storing positions at the wafer warehouse.

TABLE IV. ONE-WAY ANOVA RESULT OF $\mathrm{H}_{2}$

\begin{tabular}{|c|c|c|c|}
\hline \multirow{2}{*}{ Table Head } & \multicolumn{3}{|c|}{ ANOVA } \\
\hline & Title & $\mathbf{F}$ & Significance \\
\hline $\begin{array}{l}\text { Independent } \\
\text { variable } 1\end{array}$ & $\begin{array}{l}\text { Storing positions of barcodes in } \\
\text { the wafer warehouse }\end{array}$ & 2.46 & 0.02 \\
\hline $\begin{array}{l}\text { Independent } \\
\text { variable } 2\end{array}$ & $\begin{array}{l}\text { Failure to find the articles after } \\
\text { improvement with barcode } \\
\text { system }\end{array}$ & 3.49 & 0.04 \\
\hline
\end{tabular}

The results showed that both the storing positions of barcodes in the wafer warehouse and the failure to find the articles after improvement with barcode system have significance $<=0.05$. That suggests that for the workers, the establishment of the barcode system did improve well on the control of storing positions by the entire department; as such, $\mathrm{H} 2$ : The improvement with barcode system is significantly related to the accuracy of storing positions at the wafer warehouse is testified.

c) $\mathrm{H}_{3}$ : The improvement with barcode system is significantly related to the information transparency at the production management department.

TABLE V. ONE-WAY ANOVA RESULT OF $\mathrm{H}_{3}$

\begin{tabular}{|l|l|c|c|}
\hline \multirow{2}{*}{ Table Head } & \multicolumn{3}{|c|}{ ANOVA } \\
\cline { 2 - 4 } & \multicolumn{1}{|c|}{ Title } & F & Significance \\
\hline $\begin{array}{l}\text { Independent } \\
\text { variable 1 }\end{array}$ & $\begin{array}{l}\text { Consistence and transparency of } \\
\text { information at the production } \\
\text { management department }\end{array}$ & 3.18 & 0.03 \\
\hline $\begin{array}{l}\text { Independent } \\
\text { variable 2 }\end{array}$ & $\begin{array}{l}\text { Use of barcodes in QA } \\
\text { inspections and wafer split }\end{array}$ & 3.57 & 0.018 \\
\hline
\end{tabular}

The consistence and transparency of information at the production management department and the use of barcodes in QA inspections and wafer split both were $<=0.05$, having significant effects. For the workers, the establishment of the barcode system did improve well the consistence and transparency of information at the department. The control of batches subject to inspection had been undesirable, but, thanks to the barcode system, the information on batch and progress can now be accurately controlled. Therefore, H3: The improvement with barcode system is significantly related to 
the information transparency at the production management department was testified.

\section{2) Job satisfaction}

a) $\mathrm{H}_{4}$ : The introduction of barcode system is significantly related to employee's sense of achievement in work.

TABLE VI. ONE-WAY ANOVA RESULT OF $\mathrm{H}_{4}$

\begin{tabular}{|l|l|c|c|}
\hline \multirow{2}{*}{ Table Head } & \multicolumn{1}{|c|}{ TNOVA } \\
\cline { 2 - 4 } & \multicolumn{1}{|c|}{ Title } & F & Significance \\
\hline $\begin{array}{l}\text { Independent } \\
\text { variable 1 }\end{array}$ & $\begin{array}{l}\text { Sense of achievement and } \\
\text { identity in work }\end{array}$ & 3.75 & 0.00 \\
\hline $\begin{array}{l}\text { Independent } \\
\text { variable 2 }\end{array}$ & $\begin{array}{l}\text { Have experienced the influence } \\
\text { of work }\end{array}$ & 3.2 & 0.04 \\
\hline $\begin{array}{l}\text { Independent } \\
\text { variable 3 }\end{array}$ & $\begin{array}{l}\text { Information or knowledge } \\
\text { acquired from work results }\end{array}$ & 2.96 & 0.02 \\
\hline
\end{tabular}

Sense of achievement and identity in work that was experienced, the influence of work that was experienced, and the information or knowledge acquired from work results were all $<=0.05$, bearing significant effects. At Company A, because the improvement with the barcode system affected workers' work efficiency, that in turn affected their sense of achievement in work, as well as the knowledge and learning acquired from work, the introduction of barcode system is significantly related to the sense of achievement in employees.

b) $H_{5}$ : The introduction of barcode system is significantly related to employee's job satisfaction.

TABLE VII. ONE-WAY ANOVA RESULT OF $\mathrm{H}_{5}$

\begin{tabular}{|c|c|c|c|}
\hline \multirow{2}{*}{ Table Head } & \multicolumn{3}{|c|}{ ANOVA } \\
\hline & Title & $\mathbf{F}$ & Significance \\
\hline $\begin{array}{l}\text { Independent } \\
\text { variable } 1\end{array}$ & $\begin{array}{l}\text { Satisfaction with the current ratio } \\
\text { of workload to working time }\end{array}$ & 3.62 & 0.03 \\
\hline $\begin{array}{l}\text { Independent } \\
\text { variable } 2\end{array}$ & $\begin{array}{l}\text { Satisfaction with the current job } \\
\text { as a whole }\end{array}$ & 3.48 & 0.01 \\
\hline $\begin{array}{l}\text { Independent } \\
\text { variable } 3\end{array}$ & $\begin{array}{l}\text { Satisfaction and sense of } \\
\text { achievement brought by the work }\end{array}$ & 2.88 & 0.024 \\
\hline
\end{tabular}

For the employees, the improvement on work from the introduction of the system was significant. As the satisfaction with the current ratio of workload to working time, the satisfaction with the current job as a whole, and the satisfaction and sense of achievement brought by the work all have significance $<=0.05$, it is testified that the employees of Company A are satisfied with the assistance from the introduction of the barcode system in the improvement on their job. Therefore, the job satisfaction in employees after the introduction of the barcode system was significant.

\section{CONCLUSION}

Our findings indicated that Company A enjoyed improvement on the accuracy of storing positions, reduction of article picking time, increase in information transparency, and enhancement of sense of achievement and satisfaction in employees after it introduced the barcode system. From the analysis of the retrieved questionnaires, it is clear that at Company A under study, the introduction of barcode system helped in the total work improvement. As the improvement was made with the intention to minimize manual data processing, the organization of data arrived at that effectiveness was obtained in both work efficiency as a whole and employees' satisfaction. A barcode system is part of the logistic management system, where the logistic management information system is centered at incoming goods, sales of goods and stock. In actual planning, it is necessary to take into consideration the differences in operational needs as well as pay full attention, at the same time, association between the operation systems, flexibility and usefulness. Therefore, the observation over the recent six months could explain how a barcode system helped decrease delay in putting batches of goods in production line to reduce customer complaints.

\section{References}

[1] Landt, J. (2005). The history of RFID. IEEE Potentials, 24: 8-11.

[2] Youssef, S. M., \& Salem, R. M. (2007). Automated barcode recognition for smart identification and inspection automation. Expert Systems with Applications, 33, 968-977.

[3] Goksoy, A., Ozsoy, B., \& Vayvay, O. (2012). Business Process Reengineering: Strategic Tool for Managing Organizational Change an Application in a Multinational Company. International Journal of Business and Management, 7(2), 89-112.

[4] Chen C., Kot, A. C., \& Yang, H. (2013). A Two-stage quality measure for mobile phone captured 2D barcode images. Pattern Recognition, 46, 2588-2598.

[5] Liu, T. Y., Tan, T. H., \& Chu, Y. L., (2007), "2D Barcode and Augmented Reality Supported English Learning System," 6th IEEE/ACIS International Conference on Computer and Information Science (ICIS 2007), 5-10.

[6] Liu, T. Y., Tan, T. H., \& Chu, Y. L., (2007), "2D Barcode and Augmented Reality Supported English Learning System," 6th IEEE/ACIS International Conference

[7] Lu, W.S., G.Q. Huang and H. Li, 2011. Scenarios for applying RFID technology in

[8] W.H. Inmon(2005), "Building the Data Warehouse"

[9] Gavin, C., David, D., Greg, G., Lyle G., Jeff S. \& Joseph, T. (2003), Auto-ID in the Box: The Value of Auto-ID Technology in Retail Stores

[10] Hoppock, R. (1935). Job satisfaction. New York : Harper \& Row Inc 